\title{
URGENSI PEMBINAAN AKHLAK BAGI ANAK-ANAK PRASEKOLAH
}

\author{
Siti Zulaikhah \\ Tasamuh Institute, Jawa Tengah, Indonesia. \\ siti_zulaikah081185@yahoo.co.id
}

\begin{abstract}
Abstrak
Kemajuan di bidang teknologi informasi saat ini, memberikan pengaruh yang besar terhadap anak-anak.suka tidak suka, anakanak juga sudah mengenal media internet. Karena itu, sebagai orang tua harus turut serta mengontrol dan mengawasi putra putrinya bila berselancar dalam dunia maya. Selain pengawasan yang intensif, penananam akhlak sejak dini juga harus dilakukan. Disinilah orang tua mempunyai peran yang penting dalam pembinaan akhlak bagi anak-anaknya. Tulisan ini bertujuan untuk menunjukkan pentingnya pendidikan akhlak bagi anak usia dini. Kajian ini merupakan penelitian kepustakaan. Hasil kajian ini menunjukkan bahwa tahapan-tahapan dalam membina akhlak bagi anak-anak, pertama, memberi contoh kepada anak dalam berakhlak mulia, kedua, menyediakan kesempatan kepada anak untuk mempraktikkan akhlak mulia, ketiga, memberi tanggung jawab sesuai dengan perkembangan anak, dan keempat, mengawasi dan mengarahkan anak agar selektif dalam bergaul.
\end{abstract}

Kata Kunci: pembinaan akhlak, anak pra sekolah, peran orang tua

\section{Abstract}

THE URGENCY OF MORAL DEVELOPMENT FOR PRESCHOOL CHILDREN. The advance in information technology 
Siti Zulaikhah

recently, give a big inluence to the children. Therefore, as parents must participate to control and supervise her son when surfing in cyberspace. Besides intensive supervision, morals early planting should be done. This is where parents have an important role in the formation of character for her children. This study aims to show how importance the character education for early childhood. This study uses library research. The result of this studi showed that parents as the first educators in the family environment. Both should help each other. The roles and stages in fostering morals for children, first, to give an example to children in a noble, secondly, to provide opportunities for children to practice the noble character, the third, giving the responsibility in accordance with the child's development, and the fourth, supervise and directing children to be selective in the mix.

Keywords: moral guidance, pre-school children, the role of parents

\section{A. Pendahuluan}

Era globalisasi ditandai dengan kemajuan di bidang teknologi informasi. Kemajuan di bidang tersebut salah satunya internet, dalam hitungan detik informasi dari belahan dunia manapun sangat mudah untuk di akses dibandingkan dengan sebelum ditemukannya media internet. Berbagai informasi apapun akan dengan mudah kita peroleh, hanya mengetik satu kata saja di media pencari informasi, maka akan muncul informasi yang kita inginkan. Baik itu informasi yang positif maupun negatif. Permasalahannya sekarang adalah dengan kemajuan di bidang teknologi informasi tersebut, mau tidak mau, suka tidak suka, akan berpengaruh terhadap pertumbuhan anak. Karena itu, sebagai orang tua harus turut serta mengontrol dan mengawasi putra putrinya bila berselancar dalam dunia maya. Selain pengawasan yang intensif, penananam akhlak sejak dini juga harus dilakukan, kalau kita tidak ingin kecolongan. Anak memiliki hak yang mendasar yaitu hak untuk hidup, hak pendidikan, hak pengajaran termasuk memperoleh informasi, tapi tentunya tidak semua informasi harus diberikan kepadanya, harus disesuaikan dengan tingkatan usia mereka. Menurut Syekh Alauddin Za'tari (Republika, 27 September 2013: 4) dalam risalahnya yang berjudul Maqashid as-Syari'ah wa Dauruha fi al-Hifaz ala Huqūq ath-Tifl menyatakan bahwa Islam memandang 
seorang anak memiliki hak-hak mendasar. Hak paling mendasar yang dimiliki oleh anak ialah hak untuk hidup. Anak yang terlahir dari buah pernikahan mempunyai hak hidup yang sama. "Sesungguhnya Kami telah menciptakan manusia dalam bentuk yang sebaik-baiknya” (Qs. a-Tin [95]: 4). Karena itu, Islam melarang aborsi dan membunuh bayi yang lahir sekalipun dari hasil hubungan gelap. Hak selanjutnya adalah hak untuk memperoleh pendidikan yang layak. Pendidikan tersebut memiliki dua tujuan utama, yakni memberikan kondisi yang layak agar si anak bisa belajar agama sebagai bekal di akhirat dan tujuan kedua mencetak generasi unggul berkarakter yang siap terjun di dunia nyata. Komponennya bisa sangat bervariasi. Baik menyangkut kesiapan fisik, spiritualitas, dan intelektualitas. Maka, orang tua wajib mentransfer pendidikan tentang akidah, akhlak, dan sebagainya. Dijelaskan dalam surat at-Tahrim [66] ayat 6, "Hai orangorang yang beriman, peliharalah dirimu dan keluargamu dari api neraka yang bahan bakarnya adalah manusia dan batu; penjaganya malaikatmalaikat yang kasar, keras, dan tidak mendurhakai Allah terhadap apa yang diperintahkan-Nya kepada mereka dan selalu mengerjakan apa yang diperintahkan."

Maka dari itu, hak anak untuk memperoleh pendidikan termasuk pembinaan akhlak harus diperhatikan oleh para orang tua. Pembinaan dan pendidikan akhlak harus ditanamkan sejak usia dini, bahkan sejak masih di dalam kandungan, semisal membacakan ayatayat suci al-Quran, kisah-kisah para Nabi dan juga sahabat, hal ini akan memberikan efek yang positif bagi janin yang sedang dikandung oleh sang ibu.

Ini dibuktikan oleh riset terbaru bahwa janin telah mampu mendengar atau responsif terhadap stimuli dari lingkungan eksternala, terutama sekali terhadap pola-pola suara. Dalam suatu studi mengenai kemampuan janin mereaksi atau merespon rangsangan eksternal, Dr. Seus's meminta kepada ibu-ibu hamil untuk membacakan sebuah cerita anak-anak yang berjudul "The Cat in the Hat "dengan suara nyaring kepada bayi yang dikandungnya sebanyak dua kali sehari selama enam minggu terakhir kehamilannya. Beberapa hari setelah 
kelahiran, bayi kembali diperdengarkan pada cerita yang sama dan sebuah cerita lain yang belum pernah diperdengarkan sebelumnya. Untuk menentukan cerita mana yang lebih disukai, bayi diberi sebuah dot yang dapat merekam setiap perubahan dan peningkatan atau penurunan interval waktu menyusu. Ternyata, perubahan kecepatan dan peningkatan menyusui terjadi pada waktu bayi mendengar cerita "The Cat in the Hat". Tetapi hal demikian tidak terjadi pada waktu mendengar cerita baru. Jadi, bayi menunjukkan suatu pilihan yang jelas berdasarkan pada pengalamannya selama di kandungan ibunya (Desmita, 2012: 74-75).

Dengan demikian, melihat hasil riset tersebut pembinaan dan pendidikan akhlak sejak usia anak-anak bahkan ketika masih di dalam kandungan ibunya sangat mempengaruhi perilaku dan tingkah laku anak-anak. Disinilah pentingnya pembinaan dan pendidikan akhlak dilakukan jauh-jauh hari sebelum memasuki masa remaja, terlebih pada era globalisasi saat ini.

\section{B. Pembahasan}

\section{Kedudukan Akhlak dalam Islam}

Akhlak (akhlaq) secara etimologi adalah bentuk jamak dari khuluq yang berarti budi pekerti, perangai, tingkah laku atau tabiat. Berakar dari kata khalaqa yang berarti menciptakan. Seakar dengan kata Khaliq (Pencipta), makhluq (yang diciptakan) dan khalq (penciptaan) (Ilyas, 2000: 1). Menurut Abdullah Daraz, perbuatanperbuatan manusia dapat dianggp sebagai akhlak apabila memenuhi dua syarat sebagai berikut: pertama, perbuatan-perbuatan itu dilakukan berulangkali sehingga perbuatan-perbuatan itu menjadi kebiasaan; kedua, perbuatan-perbuatan itu dilakukan dengan kehendak sendiri bukan karena adanya tekanan-tekanan yang datang dari luar seperti ancaman dan paksaan atau sebaliknya melalui bujukan dan rayuan (Assegaf, 2014: 42).

Posisi akhlak dalam Islam memiliki kedudukan yang istimewa dan sangat penting. Hal tersebut banyak diinformasikan dalam al-Quran dan sunah Rasulullah saw. Adapun keistimewaan dan 
kedudukan akhlak dalam Islam menurut Yunahar Ilyas (1999: 6-9) dapat dilihat dalam al-Quran dan hadis berikut ini, "Bacalah apa yang telah diwahyukan kepadamu, yaitu Al Kitab (Al Quran) dan dirikanlah salat. Sesungguhnya shalat itu mencegah dari (perbuatan-perbuatan) keji dan mungkar. Dan sesungguhnya mengingat Allah (shalat) adalah lebih besar (keutamaannya dari ibadat-ibadat yang lain). Dan Allah mengetahui apa yang kamu kerjakan" (Qs. al-Ankabut [29]: 45).

Rasulullah saw. bersabda,

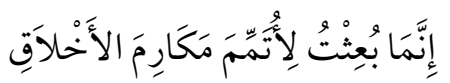

"Sesungguhnya aku diutus untuk menyempurnakan akhlak yang mulia" (HR. Baihaqi).

Rasulullah saw. bersabda,

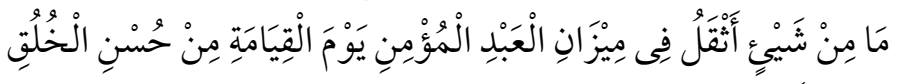

"Tidak ada satupun yang akan lebih memberatkan timbangan (kebaikan) seorang hamba mukmin nanti pada hari kiamat selain dari akhlak yang baik" (HR. Tirmidzi).

Surat al-Ankabut ayat 45 di atas menerangkan bahwa orang yang mendirikan salat tentunya tidak akan mengerjakan segala perbuatan yang tergolong keji dan mungkar. Karena, apalah artinya salat kalau dia tetap saja mengerjakan kekejian dan kemungkaran. Adapun kedua hadis di atas Rasulullah saw. menjelaskan bahwa penyempurnaan akhlak yang mulia adalah sebagai misi pokok ajaran Islam serta akhlak yang baik akan memberatkan timbangan kebaikan seseorang nanti pada hari kiamat.

Dengan demikian, tidak dapat disangsikan lagi bahwa banyaknya ayat-ayat al-Quran dan al-Hadis yang menjelaskan tentang akhlak menunjukkan bahwa akhlak menduduki posisi yang sentral dalam ajaran Islam. Jadi, tidak hanya selesai pada ibadah mahdhah saja, namun ibadah-ibadah tersebut harus dapat membuahkan hasil atau pengaruh yang positif bagi pelakunya.

\section{Fungsi Akhlak}

\section{a. Akhlak Mewujudkan Kesejahteraan Masyarakat}

Akhlak merupakan suatu alat yang digunakan untuk mengop- 
timalkan sumber daya potensi untuk mencapai kesejahteraan hidup manusia baik di dunia maupun di akhirat. Karena itu, bagaimana manusia dalam menggunakan sumber daya potensi yang tersedia untuk meningkatkan kehidupan lebih baik. Karenanya, diperlukan alat yang digunakan untuk menganalisis sekaligus membuktikan konsep al-Quran dan hadis yang secara langsung maupun tidak langsung bersentuhan dengan masalah akhlak.

\section{b. Mengungkapkan Masalah dengan Objektif}

Perkembangan akhlak bagi beberapa pihak dianggap sebagai ilmu normatif, jauh dari sentuhan ilmiah. Dengan menggunakan metodologi akhlaqul karimah ini akan mampu membuktikan bagaimana konsep akhlak menurut Sayid Usman mensejahterakan masyarakat. Sebagai sebuah metodologi yang menggunakan ketentuan umum penelitian tentunya ini bisa digunakan untuk bukti bahwa akhlaqul karimah tidak hanya bicara dalam tataran normatif. Objektivitas lebih dipercaya masyarakat daripada unsur subjektif, ini menjadi model bagi akhlaqul karimah diterima sebagai sebuah konsep yang mampu memberikan jaminan manusia untuk selamat di dunia dan akhirat.

\section{c. Meningkatkan Motivasi untuk Menggali Ilmu}

Penemuan baru akan mendorong masyarakat untuk lebih jauh menyibak kebenaran konsep akhlak, masalah perkembangan akhlak selama ini lebih banyak dipengaruhi oleh kurang adanya bukti riil dalam mempengaruhi peningkatan akhlak masyarakat. Dengan adanya upaya ilmiah maka secara tidak langsung masyarakat akan menempatkan akhlaqul karimah. Hal ini merupakan langkah awal untuk lebih memilih secara objektif konsep yang lebih baik bagi kehidupannya (Mansur, 2007: 227-229).

\section{Tipologi Anak Menurut al-Quran}

Menurut Yunahar Ilyas (2000: 174-176) menurut al-Quran, anak dapat dikelompokkan kepada empat tipologi.

\section{a. Anak sebagai Perhiasan Hidup Dunia}

Al-Quran menyatakan bahwa anak adalah perhiasan hidup 
dunia (zinatul hayah ad-dunya).

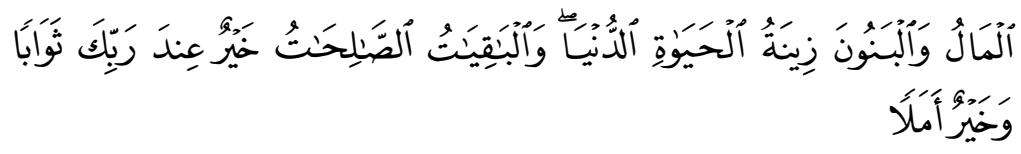

"Harta dan anak-anak adalah perhiasan kehidupan dunia tetapi amal kebajikan yang terus menerus adalah lebih baik pahalanya di sisi Tuhanmu serta lebih baik untuk menjadi harapan" (Qs. al-Kahfi [18]: 46).

Sepasang suami istri merasa rumah tangganya belum lengkap kalau belum dapat anak. Ibarat perhiasan, anak-anak berfungsi memperindah sebuah rumah tangga. Tetapi orang tua hanya memfungsikan anak sebagai perhiasan dan melupakan pembinaan dan pendidikannya akhirnya menjadikan anak tidak lebih dari sebuah "pajangan” yang secara fisik dapat dibanggakan, tetapi kualitasnya sama sekali mengecewakan, baik kualitas iman, ilmu maupun amalnya.

\section{b. Anak sebagai Ujian}

Selain sebagai perhiasan hidup dunia, anak juga menjadi ujian (fitnah) bagi kedua orang tuanya. Allah berfirman:

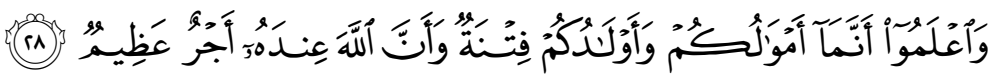

"Dan ketahuilah bahwa hartamu dan anak-anakmu itu hanyalah sebagai cobaan dan sesungguhnya di sisi Allah ada pahala yang besar" (Qs. alAnfal [8]: 28).

Orang tua diuji dengan kehadiran anaknya. Apakah anak-anak dapat melalaikannya dari beribadah kepada Allah swt. atau apakah dia mampu melaksanakan tugasnya sebagai orang tua yang baik, mendidik dan membina anaknya menjadi anak yang saleh. Fitnah juga dalam arti anak dapat menyengsarakan dan mencemarkan nama baik orang tua. Biasanya orang akan mengaitkan langsung kebaikan atau keburukan seorang anak dengan orang tuanya. Misalnya kita sering mendengar pertanyaan dari setiap orang yang kagum dengan kebaikan seorang anak atau yang heran dan jengkel dengan keburukannya adalah, "Anak siapa itu." Kalau orang tuanya mempunyai "reputasi" yang sama dengan anaknya, orang akan mengomentari, "pantas". Sebaliknya kalau ternyata orang tuanya "orang baik, komentar orang 
berbunyi, "heran". Begitulah, anak menjadi ujian dan cobaan bagi kedua orang tuanya.

\section{c. Anak sebagai Musuh}

Anak juga dapat menjadi musuh bagi kedua orang tuanya, Allah berfirman,

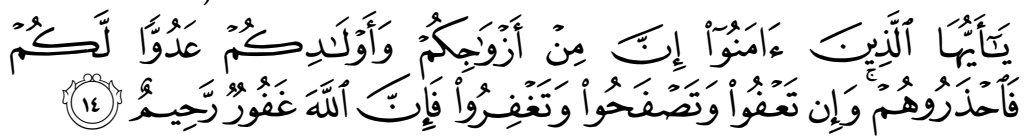

"Wahai orang-orang yang beriman! Sesungguhnya di antara istri-istrimu dan anak-anakmu ada yang menjadi musuh bagimu, maka berhati-hatilah kamu terhadap mereka dan jika kamu memaafkan dan kamu santuni serta mengampuni (mereka), maka sungguh, Allah Maha Pengampun lagi Maha Penyayang" (Qs. at-Taghabun [64]: 14)

Sungguh sangat mengecewakan kalau sampai anak menjadi musuh orang tua. Musuh bisa berarti secara fisik dan bisa juga dari segi ide, pikiran, cita-cita dan aktivitas. Bila orang tuanya di mana-mana melakukan amar ma'ruf nahi munkar, sang anak justru melakukan amar munkar nahi ma'ruf. Apabila orang tuanya membangun, anak merusak; maka pada saat itu anak sudah berada pada posisi musuh.

\section{d. Anak sebagai Cahaya Mata}

Adapun tipe yang keempat ini diistilahkan oleh al-Quran dengan qurratu a'yun (cahaya mata). Allah berfirman,

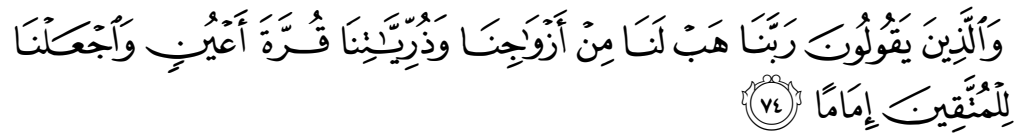

"dan orang-orang yang berkata, «Ya Tuhan kami, anugerahkanlah kepada kami pasangan kami dan keturunan kami sebagai penyenang hati (kami), dan jadikanlah kami pemimpin bagi orang-orang yang bertakwa" (Qs. al-Furqan [28]: 74).

Qurratu a'yun berarti cahaya mata, permata hati, sangat menyenangkan. Inilah tipologi anak yang ideal. Kriteria tipologi ini antara lain tunduk dan paatuh kepada Allah swt. berbakti kepada orang tua, bermuamalah dengan baik sesama manusia. Atau dengan ungkapan lain beriman, berilmu dan beramal. Hablun minallah dan hablun minannas-nya berjalan dengan baik. Tipe keempat inilah yang dapat kita sebut dengan istilah "anak saleh". 


\section{Perkembangan Anak Pra Sekolah}

\section{a. Pertumbuhan Fisik}

Pada masa ini pertumbuhan fisik berlangsung lambat dibandingkan dengan tingkat pertumbuhan selama masa bayi. Pertumbuhan fisik yang lambat ini berlangsung sampai mulai munculnya tanda-tanda pubertas, yakni kira-kira 2 tahun menjelang anak matang secara seksual dan pertumbuhan fisik kembali berkembang pesat. Tinggi rata-rata anak bertambah 2.5 inci dan berat bertambah antra 2,5 hingga 3,5 kg setiap tahunnya. Pada usia 3 tahun, tinggi anak sekitar 38 inci dan beratnya sekitar $16,5 \mathrm{~kg}$. Pada usia 5 tahun, tinggi anak mencapai 43.6 inci dan beratnya $21,5 \mathrm{~kg}$. Pada masa ini otak dan sistem saraf juga mengalami perkembangan. Meskipun otak terus bertumbuh pada masa awal anak-anak, namun pertumbuhannya tidak sepesat pada masa bayi. Pada saat bayi mencapai usia 2 tahun, ukuran otaknya rata-rata $75 \%$ dari otak orang dewasa, dan pada usia 5 tahun, ukuran otaknya telah mencapai sekitar $90 \%$ otak orang dewasa. Selanjutnya pada masa pra sekolah ini perkembangan fisik ditandai dengan berkembangnya keterampilan motorik, baik kasar maupun halus. Sekitar usia 3 tahun, anak sudah dapat berjalan dengan baik, dan sekitar usia 4 tahun anak hampir menguasai cara berjalan orang dewasa. Usia 5 tahun anak sudah terampil menggunakan kakinya untuk berjalan dengan berbagai cara, seperti maju dan mundur, jalan cepat dan pelan-pelan, melompat dan berjingkrak, berlari ke sana ke mari, memanjat, dan sebagainya yang semuanya dilakukan dengan lebih halus dan bervariasi (Desmita, 2012: 128-129).

\section{b. Perkembangan Moral}

Nilai moral ditentukan oleh kebiasaan yang dilakukan oleh orang-orang dalam suatu kelompok sosial tertentu. Perilaku bermoral dapat diartikan sebagai tingkah laku seorang anggota kelompok masyarakat yang sesuai dengan adat dan kebiasaan yang berkembang di lingkungan masyarakat tersebut. Mempelajari perilaku moral merupakan sebuah proses panjang yang dimulai sejak masa kanak-kanak sampai menjelang dewasa nanti. Anak mengalami 
perkembangan moral dengan mempelajari norma-norma yang berlaku dalam masyarakat di mana anak dibesarkan. Hal ini karena anak sama sekali tidak memiliki pengertian tentang moral pada saat ia dilahirkan. Sebelum anak bersekolah, orang tua sudah dapat mulai memperkenalkan perilaku moral kepada anak. Tujuannya agar anak mampu membedakan antara benar dan salah sesuai dengan standar kelompok masyarakat di mana anak tinggal. Seiring dengan perkembangannya nanti, terutama saat anak mulai masuk sekolah, anak akan menyadari bahwa perilaku bermoral akan membawa kemudahan baginya untuk menyesuaikan diri dan menjadi bagian dalam kehidupan bermasyarakat (Wulan, 2011: 54-55).

\section{c. Perkembangan Kepribadian}

Kepribadian adalah karakteristik yang dimiliki oleh seseorang dan mempengaruhi orang tersebut dalam berfikir, bersikap dan bertingkah laku. Mengenal kepribadian anak sejak dini, terutama saat akan mulai bersekolah, penting dilakukan oleh orang tua. Hal ini karena anak-anak yang memiliki kepribadian baik cenderung lebih mudah melakukan penyesuaian sosial daripada anak yang kurang baik kepribadiannya (Wulan, 2011: 58).

\section{d. Perkembangan Bermain}

Permainan adalah salah satu bentuk aktivitas sosial yang dominan pada anak-anak masa pra sekolah. Sebab, anak-anak menghabiskan lebih banyak waktunya di luar rumah bermain dengan teman-temannya dibanding terlibat dalam aktivitas lain. Karena itu, kebanyakan hubungan sosial dengan teman sebaya dalam masa ini terjadi dalam bentuk permainan. Permainan mempunyai arti penting bagi perkembangan kehidupan anak-anak. Menurut Hetherington dan Parke sebagaimana dikutip oleh Desmita (2012: 141-142), menyebutkan tiga fungsi utama dari permainan, pertama, fungsi kognitif. Permainan membantu perkembangan kognitif anak. Melalui permainan, anak-anak menjelajahi lingkungannya, mempelajari objek-objek di sekitarnya, dan belajar memecahkan masalah yang dihadapinya. Kedua, fungsi sosial. Permainan dapat meningkatkan perkembangan sosial anak. Khususnya dalam permainan fantasi 
dengan memerankan suatu peran, anak belajar memahami orang lain dan peran-peran yang akan ia mainkan di kemudian hari setelah tumbuh menjadi orang dewasa. Ketiga, fungsi emosi. Permainan memungkinkan anak untuk memecahkan sebagian dari masalah emosionalnya, belajar mengatasi kegelisahan dan konflik batin. Permainan memungkinkan anak melepaskan energi fisik yang berlebihan dan membebaskan perasaan-perasaan yang terpendam. Karena tekanan-tekanan batin terlepaskan di dalam permainan, anak dapat mengatasi masalah-masalah kehidupan.

\section{Pembinaan Akhlak bagi Anak-Anak Pra Sekolah}

Pembinaan akhlak dalam Islam terintegrasi dengan pelaksanaan rukun Islam. Hasil analisis Muhammad al-Ghazali seperti yang dikutip oleh Abudin Nata terhadap rukun Islam yang lima telah menunjukkan dengan jelas bahwa dalam rukun Islam yang lima itu terkandung konsep pembinaan akhlak. Rukun Islam yang pertama adalah mengucapkan dua kalimat syahadat, yaitu bersaksi bahwa tiada Tuhan selain Allah, dan bersaksi bahwa Nabi Muhammad adalah utusan Allah. Kalimat ini mengandung pernyataan bahwa selama hidupnya manusia hanya tunduk kepada aturan dan tuntutan Allah. Orang yang tunduk dan patuh pada aturan Allan dan Rasul-Nya sudah dapat dipastika akan menjadi orang yang baik. Selanjutnya rukun Islam yang kedua adalah mengerjakan salat lima waktu. Salat yang dikerjakan akan membawa pelakunya terhindar dari perbuatan keji dan munkar (Qs. al-Ankabut [29]: 45). Dalam hadis Qudsi dijelaskan pula sebagai berikut, "Bahwasannya Aku menerima salat hanya dari orang yang bertawadhu dengan salatnya kepada keagungan-Ku yang tidak terus-menerus berdosa, menghabiskan waktunya sepanjang hari untuk zikir kepada-Ku, kasih sayang kepada fakir miskin, ibn sabil, janda serta mengasihi orang yang mendapat musibah" (HR. al-Bazzar). Pada hadis tersebut salat diharapkan dapat menghasilkan akhlak yang mulia, yaitu bersikap tawadhu, mengagungkan Allah, berzikir, membantu fakir miskin, ibn sabil, janda dan orang yang mendapat musibah. Semua ini mengandung ajaran akhlak.

Selanjutnya dalam rukun Islam yang ketiga, yaitu zakat juga 
mengandung didikan akhlak, yaitu agar orang yang melaksanakannya dapat membersihkan dirinya dari sifat kikir, mementingkan diri sendiri, dan membersihkan hartanya dari hak orang lain,yaitu hak fakir miskin dan seterusnya. Pelaksanaan zakat yang berdimensi akhlak yang bersifat sosial ekonomis ini dipersubur lagi dengan pelaksanaan sedekah yang bentuknya tidak hanya berupa materi, tetapi juga nonmateri. Hadis yang diriwayatkan Bukhari berikut ini menggambarkan sedekah dalam hubungannya dengan akhlak yang mulia. "Senyumanmu untuk saudaramu adalah sedekah, dan amar ma'ruf serta nahi munkarmu juga sedekah, dan memberikan petunjuk kepada laki-laki atau kepada siapa saja yang ada di bumi yang sedang sesat, bagimu sedekah. Dan apabila engkau suka menyingkirkan batu, duri atau tulang-tulang yang mengganggu jalan bagimu juga merupakan sedekah”.

Rukun Islam yang keempat yaitu ibadah puasa, bukan hanya sekedar menahan diri dari makan dan minum dalam waktu yang terbatas, tetapi lebih dari itu merupakan latihan menahan diri dari keinginan melakukan perbuatan keji yang dilarang. Dalam hubungan ini Nabi mengingatkan, Siapa yang tidak suka meninggalkan kata-kata dusta, dan perbuatan yang palsu, maka Allah tidak membutuhkan daripadanya, puasa meninggalkan makan dan minumnya” (HR. Bukhari).

Selanjutnya rukun Islam yang kelima adalah ibadah haji. Dalam ibadah haji ini pun nilai pembinaan akhlaknya lebih besar lagi dibandingkan dengan nilai pembinaan akhlak yang ada pada ibadah dalam rukun Islam lainnya. Hal ini bisa dipahami karena ibadah haji bersifat komprehensif yang menuntut persyaratan yang banyak, yaitu disamping harus menguasai ilmunya, juga harus sehat fisiknya, ada kemauan keras, bersabar dalam menjalankannya dan harus mengeluarkan biaya yang tidak sedikit, serta rela meninggalkan tanah air, harta kekayaan dan lainnya. Hubungan ibadah haji dengan pembinaan akhlak ini dapat dipahami dalam surat al-Baqarah [2] ayat 197, "(Musim) haji adalah beberapa bulan yang dimaklumi, barangsiapa yang menetapkan niatnya dalam bulan itu akan mengerjakan haji, maka 
tidak boleh rafats, berbuat fasik dan berbantah-bantahan di dalam masa mengerjakan haji. Dan apa yang kamu kerjakan berupa kebaikan, niscaya Allah mengetahuinya. Berbekallah, dan sesungguhnya sebaikbaik bekal adalah takwa dan bertakwalah kepada-Ku hai orang-orang yang berakal"

\section{Cara Pembinaan Akhlak Kepada Anak}

Untuk membina akhlak kepada anak-anak diperlukan cara dan metode, sehingga pembinaan akhlak dapat berhasil. Paling tidak ada dua cara untuk membina akhlak pada anak-anak, yaitu cara langsung dan cara tidak langsung.

Pertama, dengan cara langsung. Nabi Muhammad saw. adalah sebagai guru yang terbaik. Karena itu, dalam menyampaikan materi ajaran-ajarannya di bidang akhlak secara langsung dapat dengan menggunakan ayat-ayat al-Quran dan hadis tentang akhlak dari Nabi Muhammad. Dengan ayat-ayat al-Quran dan hadis tentang akhlak cara langsung itu ditempuh oleh Islam untuk membawakan ajaranajaran akhlaknya. Maka wajib atas tiap makhluk mengikuti perintah Allah swt. dan Rasul-Nya. Semisal al-Quran mengajarkan supaya anak berbakti kepada ibu dan bapaknya, sebaliknya sebagai orang tua juga mempunyai kewajiban untuk membina akhlak anak-anaknya dengan cara yang terbaik, terus memelihara pergaulan baiknya di dunia dengan orang tuanya itu, walapun mungkin antara keduanya berbeda agama atau kepercayaan. (Qs. Luqman: 14-16)

Kedua, dengan cara tidak langsung. Cara tidak langsung ini dilakukan dengan cara: 1) menceritakan kisah-kisah yang mengandung nilai-nilai akhlak. Anak suka mendengarkan ceritacerita atau kisah-kisah yang diberikan oleh orang tuanya. Kisah-kisah yang mengandung nilai-nilai akhlak banyak dikemukakan dalam ajaran Islam antara lain kisah Nabi-Nabi dan umat mereka masingmasing, kisah yang terjadi di kalangan Bani Israil, kisah pemudapemuda penghuni gua (ashabul kahfi), kisah perjalanan Isra ' Mi'raj Nabi Muhammad dan lain-lain. Kisah-kisah mempunyai kedudukan dan mempunyai peranan yang besar dalam mempengaruhi kehidupan manusia, 2) melalui kebiasaan atau latihan-latihan peribadatan. 
Ibadah seperti salat, puasa, zakat, haji perlu dibiasakan atau diadakan latihan. Apabila anak-anak dibiasakan untuk mengerjakan ibadahibadah tersebut dan betul-betul dikerjakan serta ditaati, maka lahirlah akhlak Islam pada diri anak-anak yang mengerjakannya sehingga orang itu menjadi orang Islam yang berbudi luhur. Semisal, ibadah salat, tampaknya salat adalah cara paling efektif untuk membawa manusia kepada Allah yang luhur. Dengan salat manusia berhadapan langsung dengan Allah, dan berdialog secara langsung kepada Allah. Karenanya, anak-anak harus dibiasakan untuk melaksanakan ibadahibadah tersebut sejak usia dini (Mansur, 2007: 258-264).

\section{Peran Orang Tua dalam Pembinaan Akhlak bagi Anak dan Tahapannya}

Orang tua mempunyai peran yang penting dalam pembinaan akhlak bagi anak-anaknya karena orang tua sebagai pendidik pertama di lingkungan keluarga. Ayah dan ibu harus berbagi peran dalam membina anak-anaknya. Keduanya harus saling membantu, saling bahu-membahu serta kompak supaya proses pembinaan berjalan sesuai dengan rencana. Adapun peran dan tahapan-tahapan dalam membina akhlak bagi anak-anak adalah sebagai berikut:

Pertama, memberi contoh kepada anak dalam berakhlak mulia. Sebab orang tua yang tidak berhasil menguasai dirinya tentulah tidak sanggup meyakinkan anak-anaknya untuk memegang akhlak yang diajarkannya. Maka sebagai orang tua harus terlebih dahulu mengajarkan pada dirinya tentang akhlak yang baik sehingga baru bisa memberikan contoh pada anak-anaknya.

Kedua, menyediakan kesempatan kepada anak untuk mempraktikkan akhlak mulia. Dalam keadaan bagaimana pun, sebagai orang tua akan mudah saja ditiru oleh anak-anaknya, dan di sekolah pun guru sebagai wakil orang tua merupakan orang tua yang akrab bagi anak.

Ketiga, memberi tanggung jawab sesuai dengan perkembangan anak. Pada awalnya orang tua harus memberikan pengertian dulu, setelah itu baru diberikan suatu kepercayaan pada diri anak itu sendiri. 
Keempat, mengawasi dan mengarahkan anak agar selektif dalam bergaul. Jadi orang tua tetap memberikan perhatian kepada anak-anak, di mana dan kapan pun orang tua selalu mengawasi dan mengarahkan, menjaga mereka dari teman-teman yang menyeleweng dan tempat-tempat maksiat yang menimbulkan kerusakan (Mansur, 2007: 272-274).

\section{Simpulan}

Dari penjelasan di atas bahwa salah satu tanda era globalisasi adalah kemajuan di bidang teknologi informasi. Kemajuan di bidang tersebut salah satunya internet, dalam hitungan detik informasi dari belahan dunia manapun sangat mudah untuk di akses dibandingkan dengan sebelum ditemukannya media internet. Berbagai informasi apapun akan dengan mudah kita peroleh, hanya mengetik satu kata saja di media pencari informasi, maka akan muncul informasi yang kita inginkan. Baik itu informasi yang positif maupun negatif. Permasalahannya sekarang adalah dengan kemajuan di bidang teknologi informasi tersebut, mau tidak mau, suka tidak suka, anakanak juga sudah mengenal media internet. Karena itu, sebagai orang tua harus turut serta mengontrol dan mengawasi putra putrinya bila berselancar dalam dunia maya. Selain pengawasan yang intensif, penananam akhlak sejak dini juga harus dilakukan, kalau kita tidak ingin kecolongan. Anak memiliki hak yang mendasar yaitu hak untuk hidup, hak pendidikan, hak pengajaran termasuk memperoleh informasi, tapi tentunya tidak semua informasi harus diberikan kepadanya, harus disesuaikan dengan tingkatan usia mereka. Pembinaan dan pendidikan akhlak harus ditanamkan sejak usia dini, bahkan sejak masih di dalam kandungan, semisal membacakan ayatayat suci al-Quran, kisah-kisah para Nabi dan juga sahabat, hal ini akan memberikan efek yang positif bagi janin yang sedang dikandung oleh sang ibu. Ini dibuktikan oleh riset terbaru bahwa janin telah mampu mendengar atau responsif terhadap stimuli dari lingkungan eksternal, terutama sekali terhadap pola-pola suara. Posisi akhlak dalam Islam memiliki kedudukan yang istimewa dan sangat penting. Hal tersebut 
banyak diinformasikan dalam al-Quran dan sunah Rasulullah saw.

Menurut al-Quran, anak dapat dikelompokkan kepada empat tipologi, yaitu: 1) anak sebagai perhiasan hidup dunia (Qs. al-Kahfi [18]: 46), 2) anak sebagai ujian (Qs. al-Anfal [8]: 28), 3) anak sebagai musuh (Qs. at-Taghabun [64]: 14) dan 4) anak sebagai cahaya mata (Qs. al-Furqan [28]: 74).

Pembinaan akhlak dalam Islam terintegrasi dengan pelaksanaan rukun Islam. Seperti telah dijelaskan di atas bahwa dalam rukun Islam yang lima itu terkandung konsep pembinaan akhlak. Rukun Islam yang pertama adalah mengucapkan dua kalimat syahadat, yaitu bersaksi bahwa tiada Tuhan selain Allah, dan bersaksi bahwa Nabi Muhammad adalah utusan Allah. Kalimat ini mengandung pernyataan bahwa selama hidupnya manusia hanya tunduk kepada aturan dan tuntutan Allah. Orang yang tunduk dan patuh pada aturan Allan dan RasulNya sudah dapat dipastika akan menjadi orang yang baik. Selanjutnya rukun Islam yang kedua adalah mengerjakan salat lima waktu. Salat yang dikerjakan akan membawa pelakunya terhindar dari perbuatan keji dan munkar (Qs. al-Ankabut [29]: 45). Selanjutnya dalam rukun Islam yang ketiga, yaitu zakat juga mengandung didikan akhlak, yaitu agar orang yang melaksanakannya dapat membersihkan dirinya dari sifat kikir, mementingkan diri sendiri, dan membersihkan hartanya dari hak orang lain,yaitu hak fakir miskin dan seterusnya. Rukun Islam yang keempat yaitu ibadah puasa, bukan hanya sekedar menahan diri dari makan dan minum dalam waktu yang terbatas, tetapi lebih dari itu merupakan latihan menahan diri dari keinginan melakukan perbuatan keji yang dilarang. Selanjutnya rukun Islam yang kelima adalah ibadah haji. Dalam ibadah haji ini pun nilai pembinaan akhlaknya lebih besar lagi dibandingkan dengan nilai pembinaan akhlak yang ada pada ibadah dalam rukun Islam lainnya.

Karena itu, orang tua mempunyai peran yang penting dalam pembinaan akhlak bagi anak-anaknya. Orang tua sebagai pendidik pertama di lingkungan keluarga. Ayah dan ibu harus berbagi peran dalam membina anak-anaknya. Keduanya harus saling membantu, 
Urgensi Pembinaan Akhlak bagi Anak-anak Prasekolah

saling bahu-membahu serta kompak supaya proses pembinaan berjalan sesuai dengan rencana. Adapun peran dan tahapan-tahapan dalam membina akhlak bagi anak-anak adalah sebagai berikut: pertama, memberi contoh kepada anak dalam berakhlak mulia. Kedua, menyediakan kesempatan kepada anak untuk mempraktikkan akhlak mulia. Ketiga, memberi tanggung jawab sesuai dengan perkembangan anak. Keempat, mengawasi dan mengarahkan anak agar selektif dalam bergaul. 
Siti Zulaikhah

\section{DAFTAR PUSTAKA}

Assegaf, Abd. Rachman. 2014. Filsafat Pendidikan Islam: Paradigma Baru Pendidikan Hadhari Berbasis Integratif-Interkonektif, Jakarta: Rajawali Pers.

Desmita. 2012. Psikologi Perkembangan. Bandung: PT Remaja Rosdakarya.

Ilyas, Yunahar. 2000. Kuliah Akhlaq, Yogyakarta: Lembaga Pengkajian dan Pengamalan Islam (LPPI).

Mansur. 2007. Pendidikan Anak Usia Dini dalam Islam, Yogyakarta: Pustaka Pelajar.

Nata, Abuddin. 2013. Akhlak Tasawuf dan Karakter Mulia, Jakarta: Rajawali Pers.

Wulan, Ratna. 2011. Mengasah Kecerdasan Pada Anak, Yogyakarta: Pustaka Pelajar.

REPUBLIKA, Jumat, 27 September 2013. 